\title{
The history of renovation design of the front facade of the Main Post Office Building in Lublin
}

\author{
Elżbieta Pytlarz \\ Faculty of Architecture, Town and Space Planning, Lublin University of Technology, \\ e-mail: e.pytlarz@pollub.pl
}

\begin{abstract}
In this article it is presented a ranovation process of the Post Office building in Lublin held in 2001 - 2003. The location of thic edifice in the main street and the same time of the frontage of the central square raises the status of this building particularly that its facade is the background of numerous official celebrations and meetings of the authorities and citizens of Lublin. The author of this article describes designing solutions and also the cooperation process of architect, client, conservator and performer. The photographs showing the facade of the Main Post Office building in Lublin before its restauration and the effect after it enable a reader to compare the facade of the building from the past to its contemporary state.
\end{abstract}

Key words: Lublin, Main Post Office building, facade renovation, illumination, client, designer, conservator.

\section{Introduction}

The location of the Polish Post Office Building in the center of the city raises the status of this edifice to one of the most important buildings in Lublin. Being an architectural element of the frontage of Litewski Square, the front facade of the building is preserved by a conservator (The enrolment...No.A/588 [12]). Considering the location of the square in Krakowskie Przedmieście Street, the main street in the city linking the Old Town with the municipal park and leading up to the area of the two universities (the Catholic University and the Maria Curie Skłodowska University), the space of the square is the site of numerous official celebrations and meetings of the citizens of Lublin. Thus, the Post Office Building becomes the background of these events which are very often recorded on film reels.

\section{The history of renovations: $1921-2001$}

The oldest part, which was rebuilt and which had storeys added in 1921-24 according to Bohdan Kelles - Krauze's design (Kurządkowska [7]), has endured in its unchanged form up till now. Since 1924 the building has been restored several times. In 1938 its roughcast was renovated and its plinth course was covered up with clinker (APL [1]). In 1950 the outer walls of the building were renovated and in the period of 1953 - 1958 the part of so called "the new post office building" was added, which was the eastern wing of telegraph after J. Ogórkiewicz's design (Kurządkowska [7]). In the 70 - ties of the 19 th century the structure was extended 
from the side of the back yard and at the same time the complete refurbishment of the main building (Pastuszak [10]) took place [Photo 1].
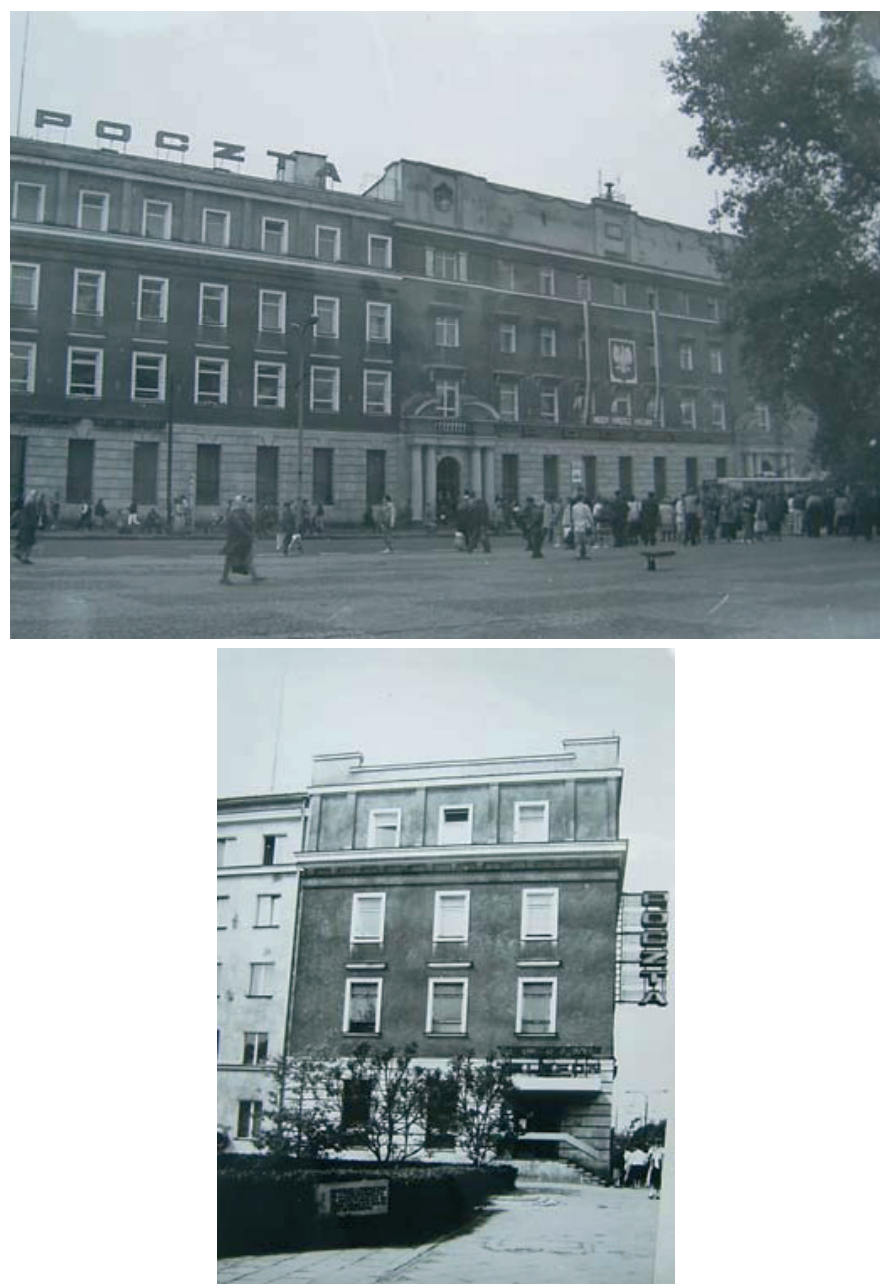

Photo 1. View of the Main Post Office Building after the repairs held in the 70 - ties.

After a twenty - year break, in 1994, all the windows in the building were replaced. (Jamiołkowska [4]). The following year a ramp for the disabled was built at the entrance from J. Czechowicz Square, (Jabłoński and Misztal [3]) and in 1996 the facade was lit with floodlights fitted to the walls (Moniak [9]). In 2000, an external lift was constructed on the side of the backyard (Bajun, Makaruk and Patro, [2]). All the repairs held since the complete refurbishment in the 70 ties have only partially intervened and influenced the changes of the building. There were no works connected with the renovation of the front facade during that time.

\section{Facade renovation: $2001-2003$}

In 2001, the author's Architect's office Investprojekt Partner 6, Ltd won the tender put in the investment services of the Post Office, to create an architectural 
and structural renovation design for the Main Post Office Building facade. During initial negotiations with the Client, the design assignment formulated as "refurbishment design" was changed into a "renovation design", although the name used in the tender documents had to be maintained in the working plans. All the cooperating representatives of the Post Office shared our opinion that the structure should not only be renovated but also embellished [Photo 2].

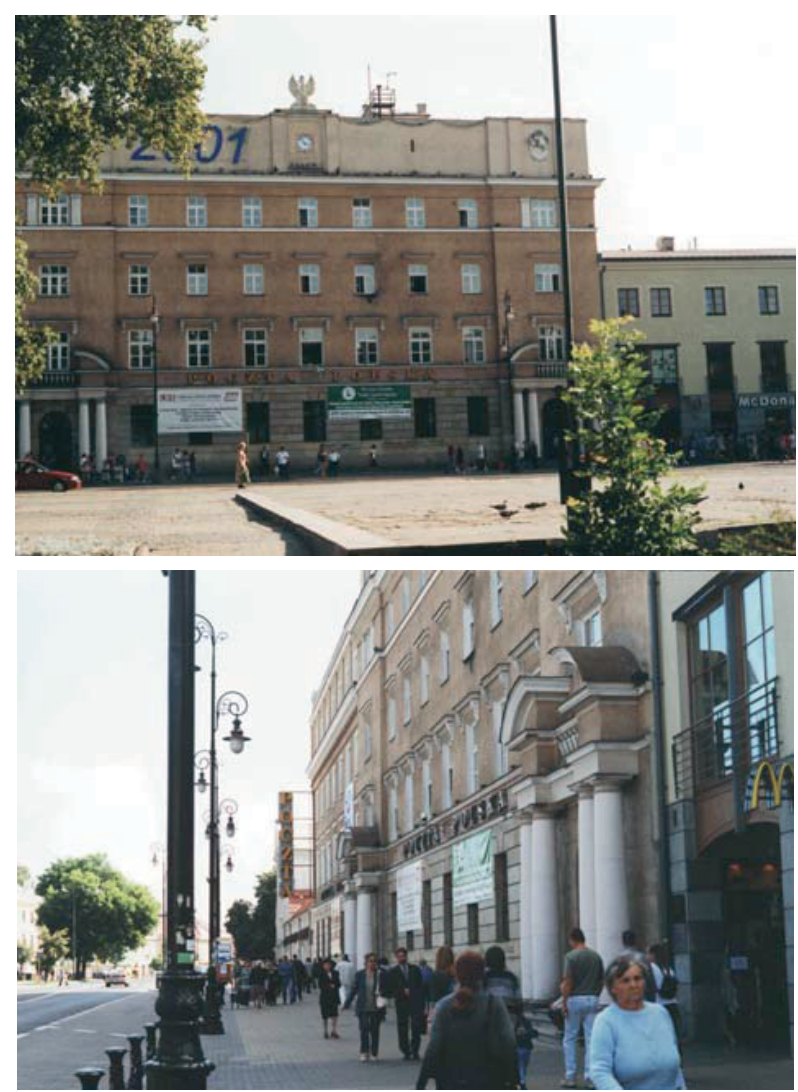

Photo 2. View of the Main Post Office Building, 2001.

As an architect, I faced a very difficult task of convincing the Client to take decisions concerning the design. One of the controversial issues was the advertisements on the building, another issue was the need to rebuild the side entrance from J. Czechowicz Square (the sloping path for the disabled was built a few years earlier, Jabłoński and Misztal [3]). The next problem concerned the way of renovating the plinth course of the building made of sandstone, the material which is susceptible to getting dirty and wet. In the Client's opinion the only solution to the problem was the replacement of the sandstone with another hard and easy to keep stone. A very explicit and firm conservator's opinion of not allowing to remove the sandstone off the front facade changed after some new design concepts had been presented. The Client got the permission to put granite onto the part of the plinth course just below the windows and also onto the part of the eastern wall of the building at the side entrance from Czechowicz Square. At the same time an idea sprang up to place a strip of granite plates around the building and connect it with the already exist- 
ing pavement through a belt of granite stones. According to the first idea of the building's illumination, floodlights lighting up the front wall of the building from the floor level were to be fixed among the granite plates on the ground. The idea of illumination was changed but the granite belt was built which, in my opinion, softens the vicinity of the building's plinth ground course made of precious stone and the pavement made of yellow concrete stones [Photo 3].
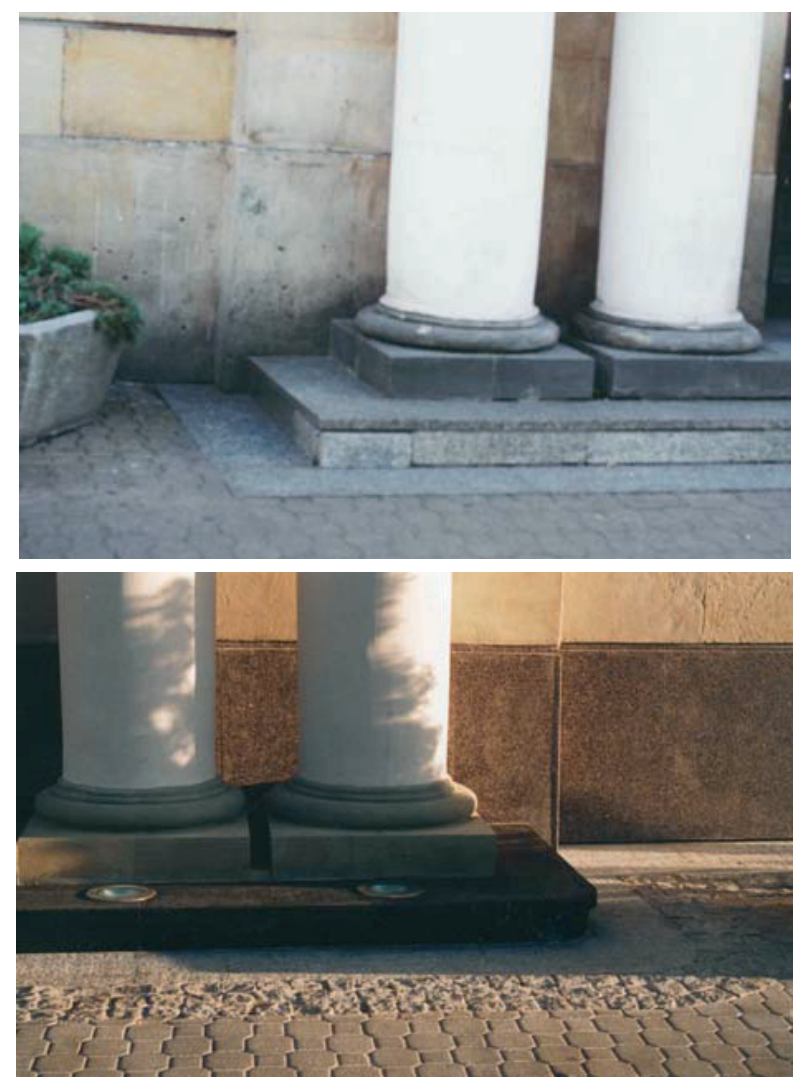

Photo 3. View of the pavement at the main entrance before and after renovation.

It was very difficult to convince the Client to make advertising inscriptions imitating bronze casts, and to remove neon lights. Finally, the concept of advertisements was accepted on condition that inscriptions were strongly illuminated.

This renovation was aimed at making the front wall of the building look like it used to in the period between the two World Wars. The design and historical documents found in the archives of the Conservation Authorities Office of the Lublin Province were the basic material for the project. After the initial analysis of available papers it appeared that none of them contained detailed drawings of the front wall of the Post Office building so, before getting to work on the design it was necessary to list all the architectural details and components such as outer stairs, and the sloping path for the disabled, and to present the state of devastation of particular parts of the building in technical expertise. Working plans concerning the state of the building in 2001 became a part of the architectural and structural design made by Architect's Office "Investprojekt Partner 6" (Pytlarz [11]). In a complex, multiline 
study the technique of facade renovation, and the colours were chosen. The basis for the choice of suitable paints was the opinion that the colour lighter than the sandstone placed on the "tall" plinth course of the building would make it look "lighter" and, not so "overwhelming" as before.

In the design there were suggested plain mineral plasters containing trass, which are more resistant to dirt than the existing spotted ones. This decision made the workers put the plasters onto the walls precisely and carefully. During the implementation of the project three shades of paints were tested. What is more, the colour suggested in the previous designs from 1993 (Kręglicki and Lakutowicz [5]) and 1994 (Kręglicki and Lakutowicz [6]) was also used. Having done two trials, the colour used in my design was chosen (Pytlarz [11]) [Photo 4].
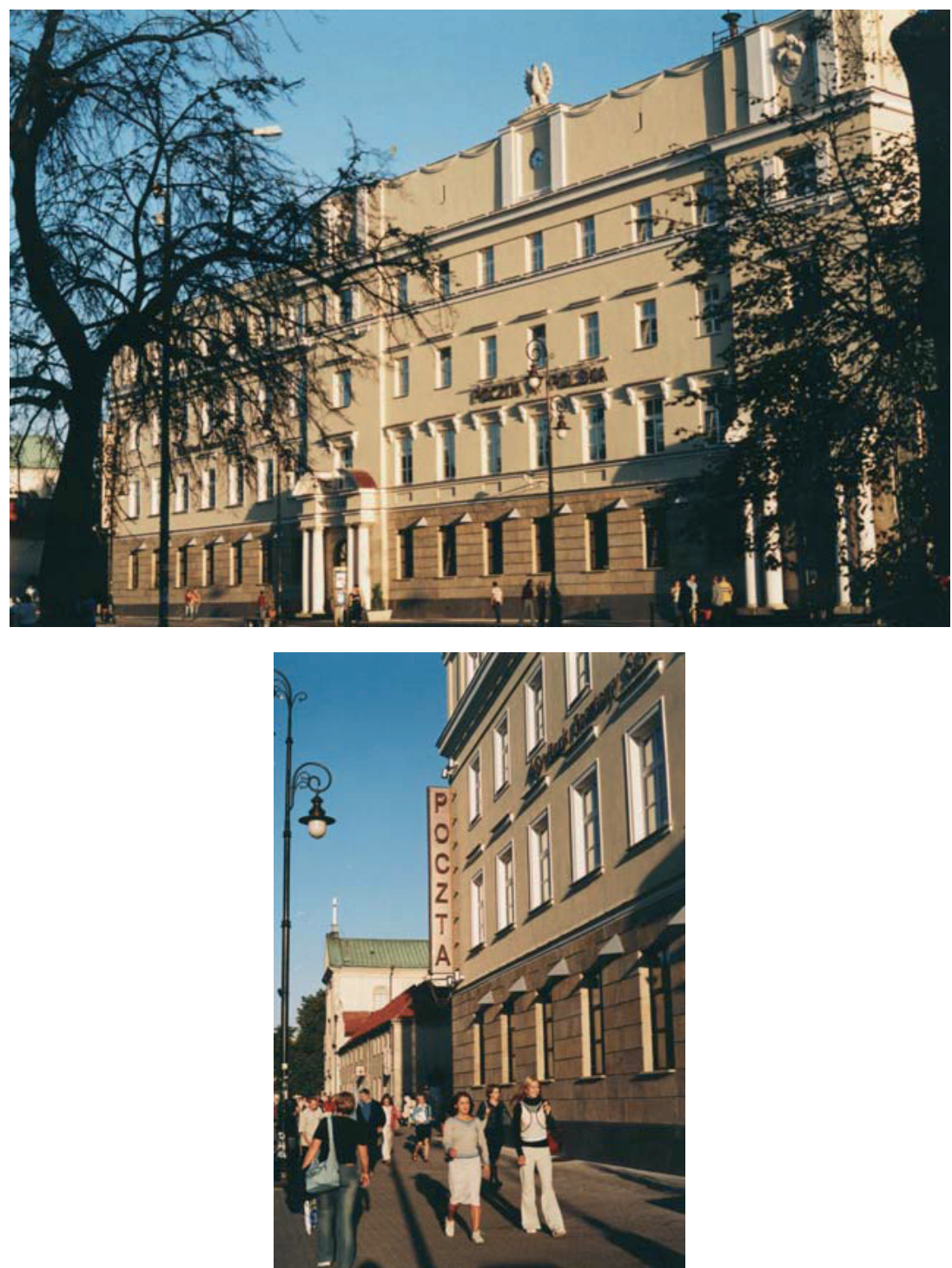

Photo 4. View of the Post Office Building after renovation, 2000. 
Granite stone for the plinth course and for the trim surrounding the building was also chosen from numerous samples. I must admit that my cooperation with the building company "Mitex", the Conservator Dariusz Kopciowski and the Investment Supervisors was really very efficient. Subcontractors were searched for in the whole country because in the Lublin district there was no firm which would be able to make according to the design either advertising inscriptions (metal letters spatially formed and then painted with powder) or the vertical inscription as well as the roof over the side entrance designed of brass pipes (Wójtowicz [13]) [Photos 5 and 6]. Brass was not chosen accidentally in the design because the roofs over neighbouring entrance to the Polish Telecommunication Building are made in the same way (steel pipes with an external coat imitating brass).

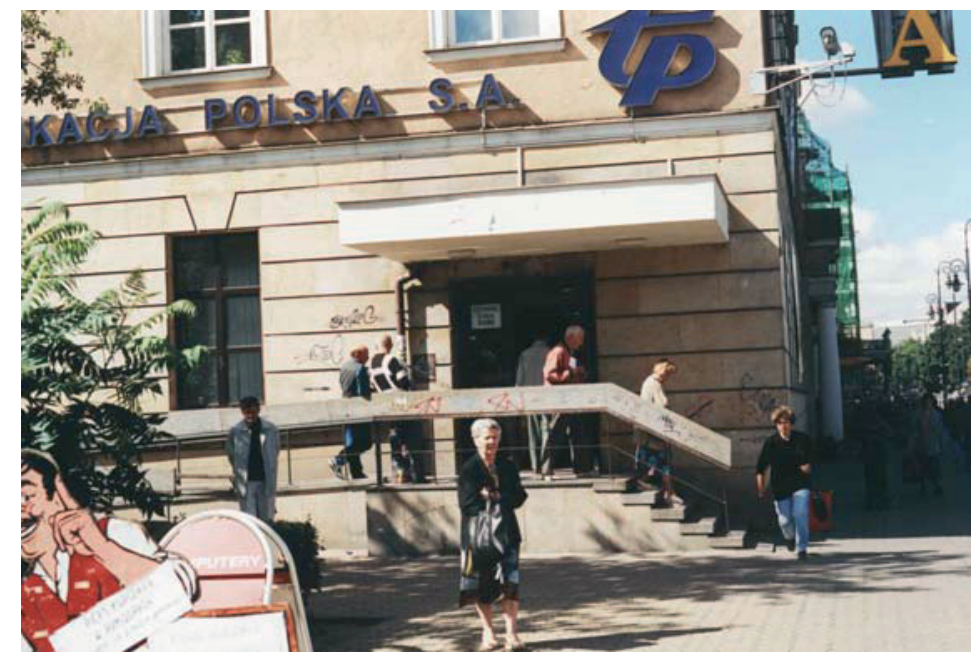

Photo 5. View of the entrance to the building in Czechowicz Square, 2001.
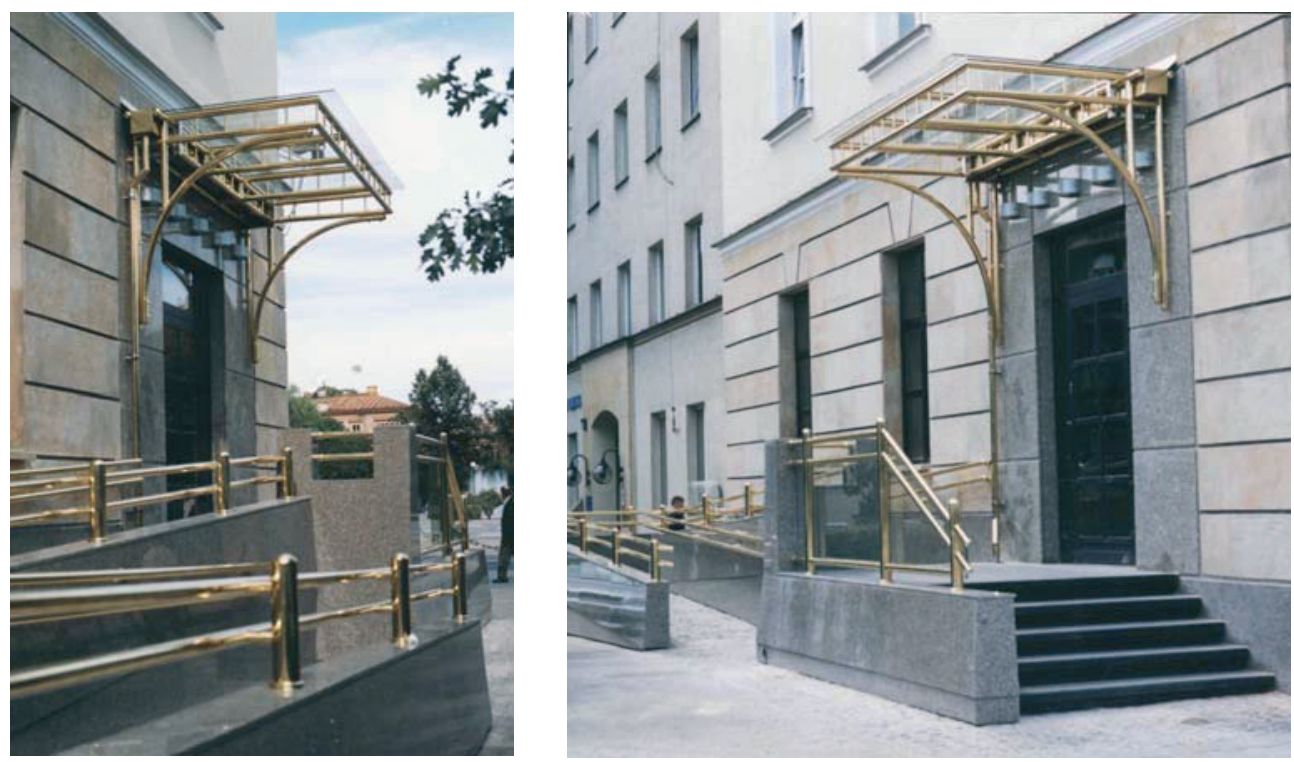

Photo 6. View of the side entrance from J. Czechowicz Square, 2003. 
In the course of the project unpredictable problems appeared. One of them was the lack of foundations under the existing stairs at the two entrances to the building in Krakowskie Przedmieście Street. The stone stairs blocks were situated directly on the ground. Another thing was the protest of the Society for Animal Protection against the designed precautions against pigeons which were gathering on the attic cornices of the Post Office Building. Later it turned out that the system of precautions chosen from many others was harmless because of its special spiral construction preventing the birds from getting hurt while landing down on their favourite places.

The design of building's illumination was a separate piece of the documentation (Marciniak and Pytlarz [8]).

"Uniform" illumination of the Post Office Building facade recommended by the Conservator appeared to be practically impossible to implement. The only solution was to fix floodlights onto street lamps so called "crosiers". The concept of illumination of this kind was created and tested in cooperation with the company "Thorn" [Photo 7]. The weight of the floodlights with adequate power to illuminate the area of wall surface was so big that it would have been necessary to change the construction of the street lamps. The Bureau of Council Economy did not accept the idea and the design had to be changed.

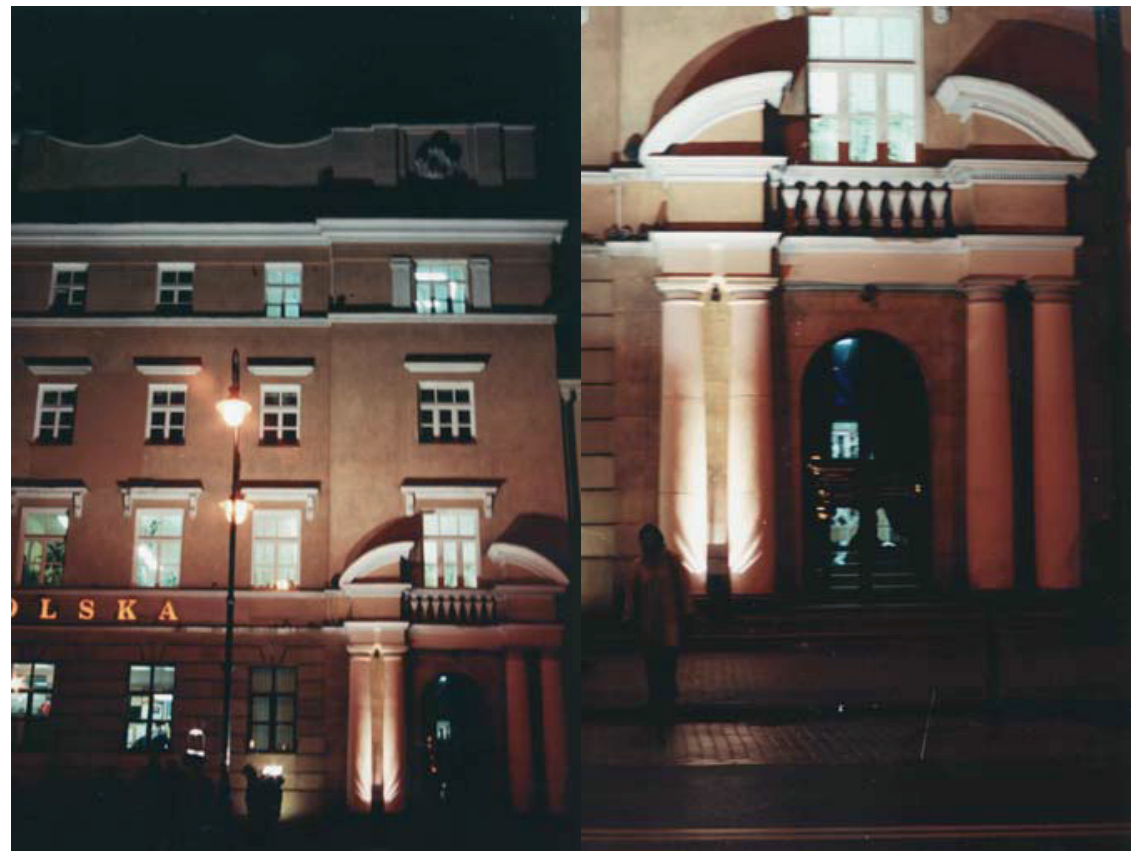

Photo 7. A picture of an illumination test, 2002.

In my files I have preserved all the illumination tests of the electronically made model of the Post Office Building. There are about 30 pictures presenting the bulky mass of the building from various sides depending on the kind and location of lights. The final version of the design made in cooperation with the engineer Marek Marciniak (the illumination design) and the engineer Sławomir Kotowski („Luxmat” Company), was accepted by the Client. The Conservator in Lublin 
suggested reducing the illumination of advertising inscriptions which, in my opinion, resulted in spoiling the effect of evenly lit building facade. Considering the costs of the designed illumination system linear lamps, which were to illuminate attics and cornices of the Post Office Building had to be changed into connected fluorescent lamps which accentuate the tallest parts of the front facade with cool and strong light too intensively [Photo 8].

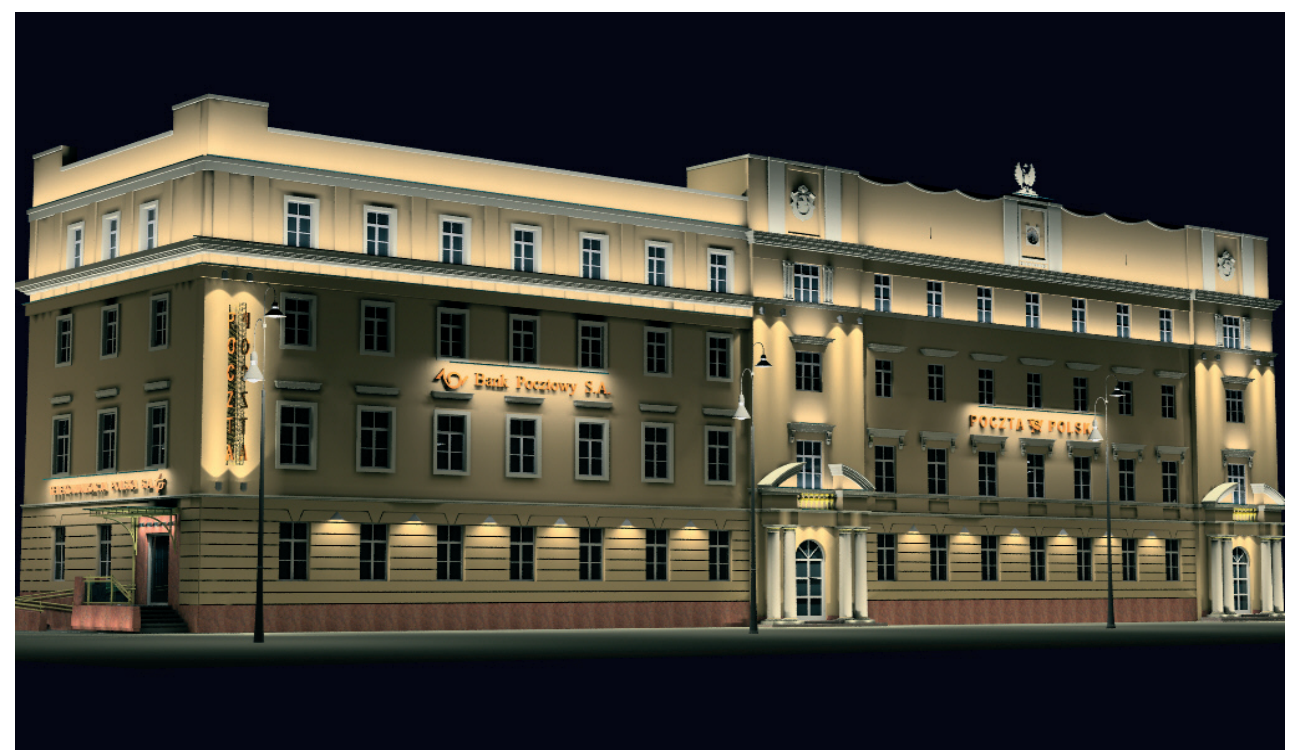

Photo 8. The illumination design of the Main Post Office Building in Lublin - visualization, 2003.

I leave the assessment of the design and project completion to specialists. As for me, it was a very important professional experience. I am also satisfied with the fact that no showy advertisement have been placed on the renovated walls so far. This makes the Post Office Building stand out of the buildings forming the frontage of Krakowskie Przedmieście Street, the street which should be the "salon" of the city of Lublin.

\section{Conclusion}

The quality of renovation of edifices depends not only on clients' financial support but also on their awareness of the problem. Extremely important is the common ability of understanding and cooperation of a client, disigner and a conservator. The dialogue leading to making final settlements and realisation decisions is necessary at every stage of designing and performing a task. The ability of convincing a client to accept accurate designing solutions is on the side of a designer and very often it demands a lot of determination.

\section{References}

[1] APL, Inspectorate Inspection, c.n. 2131.

[2] Bajun M., Makaruk B.,Patro R., A design of the ExternalLift Shaft at the Post office Building, Lublin 2000, in the archives of the The Provincial Office for Protection of Monuments in Lublin, c.n. 13387. 
[3] Jabłoński R., Misztal K., A structural Design of the Slope Path for the Disabled at the Post office Building on the side of the J. Czechowicz Square, Lublin 1995, in the archives of the provincial Beauro for Preservation of monuments in Lublin, c.n. 5867.

[4] Jamiołkowska J., A Design of Woodwork Changes in the Post Office Building, Lublin 1994, in the archives of the Provincial Beauro for Preservation of Monuments in Lublin, c.n. 4860.

[5] Kręglicki L., Lakutowicz A., The Main Post Office. A design of Colouring Worked out on the Basis of Sounding Tests of Plasters and Painting Coats, Lublin 1993, in the archives of POPM in Lublin, c.n.4772.

[6] Kręglicki L., Lakutowicz A., The main Post Office Building. A development of the Frontage - Elevation Colouring, Lublin 1994r, in the archives of POPM in Lublin, c.n . 4756.

[7] Kurzadkowska A., The Historical and Town-planning study to the Detailed Plan of the Center of Lublin, complete edition mps PPPKZ o/Lublin, 1969.

[8] Marciniak M., Pytlarz E., Lublin, the Krakowskie Przedmieście Street, the Main Post Office Building - A Building Design of Illumination of the Structure, Lublin 2003, in the archives of POPM in Lublin, c.n. 16049.

[9] Moniak J., A Design of Illumination of the Main Post Office Building Elevation, Lublin 1996, in the archives of the PBPM in Lublin, c.n.6569.

[10] Pastuszak.Z., The Post Office Building in the Krakowskie Przedmieście Street 46-56, historical Documentation, PUA SARP Lublin, 1989 in the Provincial Beauro for Preservation of Monuments, c.n. 1190.

[11] Pytlarz E., A design of Architectural and Structural Repairs of the Main Post Office Building Elevation in the 50 Krakowskie Przedmieście Street in Lublin - Architecture, Lublin 2001, in the archives of POPM in Lublin, c.n.14975.

[12] The enrolment into the Register of Monuments of the Lublin Province on 10.04.1972 No.A/588, p.396-397.

[13] Wójtowicz W., A design of Architectural and Structural Repairs of the Main Post Office Building Elevation in the 50 Krakowskie Przedmieście Street in Lublin - Construction, Lublin 2001, in the archives of POPM in Lublin, c.n.14976. 